\title{
Effect of Decreasing Saponin Levels to Nutrition of Extracted Moringa Leaf Powder
}

\author{
Yuanita Indriasari ${ }^{1}$, Fitriani Basrin ${ }^{2} \&$ Miming Berlian Hi. Salam ${ }^{2}$ \\ ${ }^{1}$ Processing of Agricultural Products Study Program, Politeknik Palu, Palu - Central Sulawesi, Indonesia \\ ${ }^{2}$ Processing of Agricultural Products Study Program, Politeknik Palu, Palu - Central Sulawesi, Indonesia \\ Corespondence: Yuanita Indriasari., Processing of Agricultural Products Study Program, Politeknik Palu, Central \\ Sulawesi, Indonesia. E-mail: yuanitadidi@gmail.com
}

\author{
Received: April 3, $2019 \quad$ Accepted: April 24, $2019 \quad$ Online Published: July 29, 2019 \\ doi:10.5539/jfr.v8n5p41 URL: https://doi.org/10.5539/jfr.v8n5p41
}

\begin{abstract}
Moringa oleifera leaves have been used as food material because it has high nutritional value. Many research have been conducted on moringa leaves extract as functional food and the additional material of nutrient for some food products (biscuit, bread, jelly drink), which it looked that adding moringa leaves extract above 5\% decrease the consumer acceptance level toward the product because of the strongest unpleasant aroma and bitter taste, which is caused by saponins content in moringa leaves extract is still high enough.This study aimed to obtain the optimal temperature and time of blanching process to reduce saponin level, and the appropriate solvents to extract nutrients from Moringa oleifera leaves so that Moringa leaves flour is obtained with no bitter taste (low saponin) and nutritious (water, protein, optimal vitamin $\mathrm{C}$ and vitamin A) as fortification ingredients for various food products. The results showed that the blanching treatment at $75^{\circ} \mathrm{C}$ for 5 minutes (T1W1) combined with $70 \%$ ethanol (P1) solvent was able to produce Moringa leaves flour with the lowest saponin content of $0.790 \%$, but with nutrients that still met the requirements, namely water $6.508 \%$, protein $28.705 \%$, Vitamin C $90.77 \mathrm{mg} 100 \mathrm{~g}^{-1}$ and Vitamin A $3590 \mu \mathrm{g} 100 \mathrm{~g}^{-1}$.
\end{abstract}

Keywords: Moringa leaves, blanching, maceration, saponin

\section{Introduction}

Moringa leaves can be a source of nutrients for all age groups. Fuglie (2001) reported that enough with $8 \mathrm{~g}$ of Moringa leaves powder a day can contribute nutrients to toddlers (1-3 years), namely $14 \%$ protein, $40 \%$ calcium, $23 \%$ iron and almost all vitamin A needs. Whereas in 100 Moringa leaves powder powder, can provide more than one third of the needs of calcium, iron, protein, copper, sulfur and vitamin B of women of childbearing age. The high nutritional content of Moringa leaves makes it as an alternative ingredient that can be added to various processed foods to increase nutritional value (fortification).

Several studies have been conducted to examine the effect of adding Moringa leaves extract to some processed foods such as bread and biscuits (Kholis \& Hadi., 2010; Sengev et al., 2013). From the study it was known that with the higher concentration of Moringa leaves extract added, the higher the nutritional value, but the level of consumer acceptance declined. This is due to the strong aroma of Moringa leaves caused by high saponin content. Saponins are compounds in the form of glycosides which are widespread in higher plants. Saponin forms colloidal solutions in water and forms a solid foam if it is shaken and not disappear with the addition of acid (Harborne., 1996).

According to Mackar and Becker (1996), there are $81 \mathrm{~g} / \mathrm{kg}$ saponin on fresh Moringa leaves. The bitter taste and aroma arising from saponins affects the level of consumer acceptance of processed food products fortified with Moringa leaves extract. This means that to increase the acceptance of food products enriched with Moringa leaves flour, the unpleasant aroma and bitter taste must be reduced, or the same as reducing the levels of saponins present in Moringa leaves before further processing.

The saponin content in some vegetables can be reduced by heat treatment such as boiling and hot steam use (Nkafamiya et al., 2006; Adeboye \& Babajide., 2007).

Indriasari et al (2016) has conducted a study to reduce saponin levels in Moringa leaves extract flour. The results showed that blanching at $85{ }^{\circ} \mathrm{C}$ for 7.5 minutes reduced saponin to $40 \%$, but the nutrient content such as protein 
and vitamin $\mathrm{C}$ was significantly reduced due to temperature treatment. In addition, the lack of nutrition is also caused by the maceration process which is only able to extract no more than $50 \%$ nutrient of Moringa leaves so that the nutrient content of Moringa leaves extract is not optimal even tends to reduce after further processing.

Based on this, further research was carried out by modifying the blanching treatment and the use of two types of polar solvents namely ethanol and methanol, as well as the utilization of Moringa leaves pulp after extracting as raw material for Moringa leaves flour, which is expected to produce Moringa leaves flour with lower saponin content and nutrients higher than previous research.

\section{Methodology}

\subsection{Material}

This research used moringa leaves that were obtained from the moringa plants grow in Palu District, Central Sulawesi Province. The characteristic of moringa leaves used is dark green, commonly the size is $1.2-2 \mathrm{~cm}$ and the wide is $0.6-1 \mathrm{~cm}$, also oval shape. Other chemicals used were ethanol, aquades and methanol obtained from chemical distributors from Makassar District, South Sulawesi Province.

\subsection{Research Methods}

\subsubsection{Blanching Process}

The study used a Factorial Completely Randomized Design (CRD) with two main factors, namely the temperature variable $\left(75{ }^{\circ} \mathrm{C}, 85^{\circ} \mathrm{C}\right.$ and $\left.95{ }^{\circ} \mathrm{C}\right)$ and the blanching process time (5 minutes and 7.5 minutes), and the subfactor namely the type of solvent (methanol and ethanol).

The first step in this study was to reduce saponin levels using the blanching process, where as many as $100 \mathrm{~g}$ of Moringa leaves were blanched in $600 \mathrm{ml}$ of water with temperature and processing time according to the treatment. To prevent a significant reduction in nutrients due to this process, the treatment temperature used was below $100{ }^{\circ} \mathrm{C}$ with no more than 7.5 minutes (according to the study conducted by of Indriasari et al., 2016). In addition, the addition of Moringa leaves into water is done when the temperature reached the treatment temperature to minimize contact between Moringa leaves and hot water. After being cloned, the leaves of moringa were dried for 5 minutes.

\subsubsection{Maceration and Extraction Processes}

The moringa leaves that have been planted are then crushed using a blender, then weighed again. After that, the extraction process was carried out by maceration method according to the study of Vongsak et al (2013), namely:

- Moringa leaves that have been blended and weighed, macerated separately with ethanol $70 \%(1: 20, \mathrm{~b} / \mathrm{v})$ and methanol $70 \%(1: 20, \mathrm{~b} / \mathrm{v})$ for 72 hours at room temperature $\left(28 \pm 2{ }^{\circ} \mathrm{C}\right)$, carried out occasional shake.

- The extract is filtered and the residue on the filter paper is extracted again with the same process and solvent until saturated. Moringa leaves that have been extracted (pulp) are then dried using a cabinet dryer at a temperature of $60-70{ }^{\circ} \mathrm{C}$ for 24 hours, and mixed.

\subsubsection{Chemical Analysis}

The chemical composition analysis was determined by the AOAC series method (Horwitz et al., 2010): vitamin A by AOAC official method number 992.04, vitamin C (AOAC number 984.26), protein content (AOAC number 967.12). Saponin content measured using spectrophotometer-uv method, with stages as follow: $0.1 \mathrm{~g}$ dry leaves up to constant weight then they were crushed with mortal until it became smooth powder, after that it was dissolved in $10 \mathrm{ml}$ ethanol $70 \%$ in a reaction tube. The powder was extracted in bath on $180{ }^{\circ} \mathrm{C}$ within 15 minutes. The absorbance of the extracted result was measured by using spectrophotometer UV on the length of wave $365 \mathrm{~nm}$ and used saponin Merck as standard solution. The read value concentration is saponin level (Stahl., 1985).

\subsubsection{Statistical Analysis}

The data obtained were subjected to statistical Analysis of Variance (ANOVA) (Steel \& Torrie., 1991), and the significant difference among the means was compared with the Duncan's Multiple Range Test (DMRT) with a probability $\mathrm{p} \leq 0.01$.

\section{Results and Discussion}

\subsection{Saponin Levels}

The result of the variance analysis showed that the interaction between the temperature and time of the blanching process applied to Moringa leaves was very significant $($ Fcount $=5326.8>$ Ftab $(\alpha=0.1)=6.93)$ to reduce 
saponin levels, whereas for the solvent type was too influential. This means that there are differences in response between treatments due to the treatment of temperature and time used.

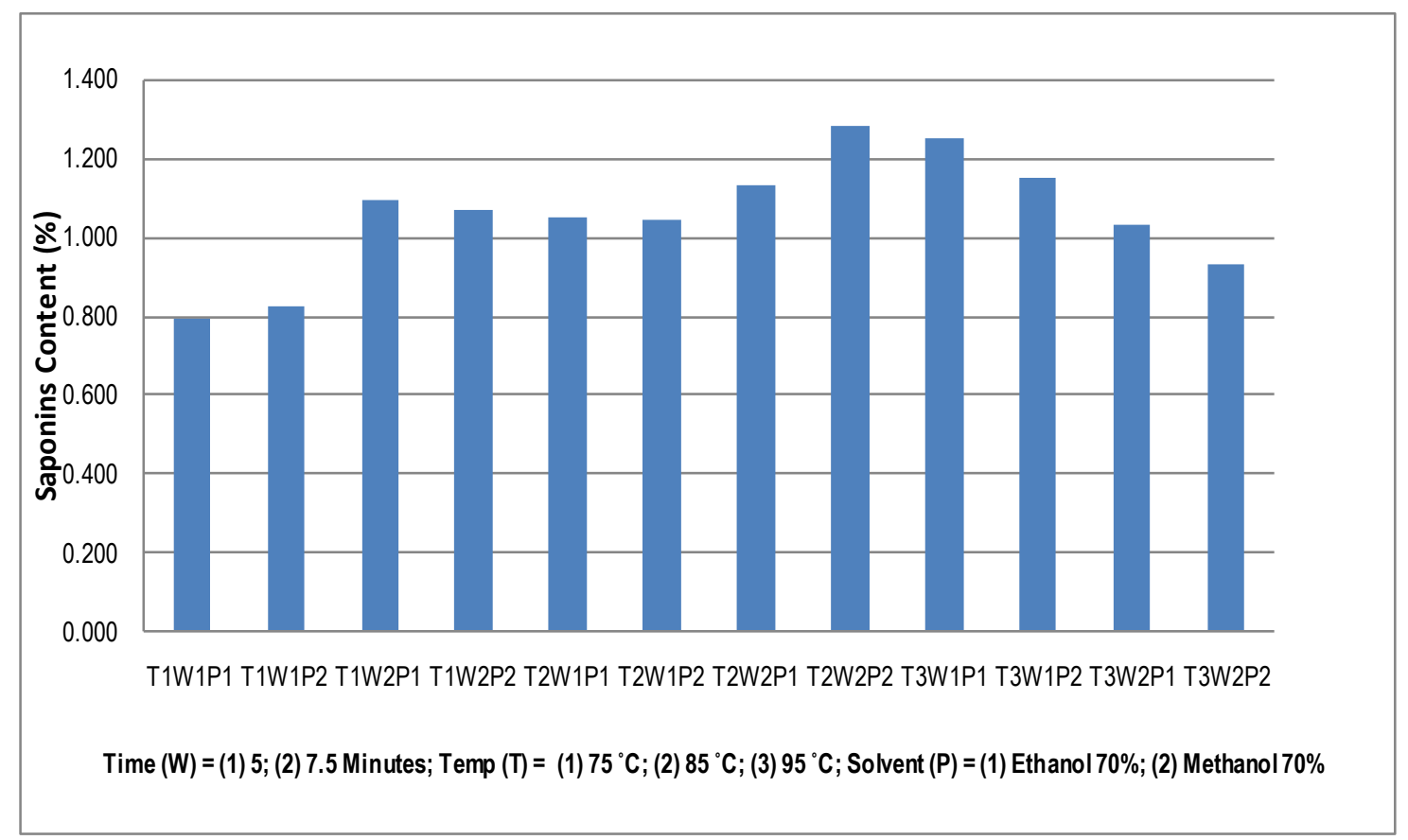

Figure 1. Saponins Content on Extracted Moringa Leaves Powder Under Different Time, Temperature and Solvent

Based on figure 1 it was found that the lowest average value of saponin level was $0.790 \%$ obtained from blanching treatment using temperature of $75^{\circ} \mathrm{C}$ for 5 minutes and extracted by applying ethanol of $70 \%$ T1W1P1). Meanwhile, the highest average value of saponin level was obtained from blanching treatment using temperature of $85^{\circ} \mathrm{C}$ for 7 and a half minutes and extracted by applying ethanol of 70\% (T2W2P2) of $1.280 \%$. The findings also show that saponin level on Moringa leaves can be reduced by applying a certain temperature and time on the blanching process. It can be seen on the percentage value of saponin level which tends to increase when the temperature rises.

Blanching treatment using boiled water at a temperature of $95-100{ }^{\circ} \mathrm{C}$ can soften the vegetable wall tissue so that the water and the compounds contained therein can enter osmosis due to high membrane/tissue permeability (Ogbonnaya \& Chinedum., 2013). This results in high levels of moringa leaves saponins after blanching at temperatures above $75^{\circ} \mathrm{C}$.

From this study, it was found that the best saponin level is the lowest level, which is T1W1P1 $(0.790 \%=0.79 \mathrm{~g}$

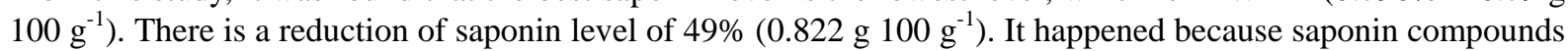
characterized with easily dissolved in the water, so the blanching process by boiling it in the hot water can reduce the saponin level significantly.

\subsection{Nutrition Levels}

Based on DMRT $(\alpha=1 \%)$ further test, it was found that the difference in response between treatments was caused by the interaction of temperature and time of the blanching process applied to Moringa leaves, but the temperature and time treatment had a separate effect, where the more dominant temperature treatment affected the protein content. Seen from the interaction if time (W) is constant, protein levels tend to be lower with increasing temperature. 
Table 1. Nutrients Content on Extracted Moringa Leaves Powder Under Different Time, Temperature and Solvent

\begin{tabular}{|c|c|c|c|c|}
\hline \multirow{2}{*}{ Variable } & \multicolumn{4}{|c|}{ Parameter } \\
\hline & Protein $(\%)$ & 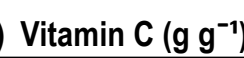 & Vitamin $A\left(g^{-1}\right)$ & Water (\%) \\
\hline TOWOPO (Control)* & 25.080 & 8.468 & 0.360 & - \\
\hline T1W1P1 $\left(75^{\circ} \mathrm{C}, 5\right.$ Minutes, Ethanol) & $28.705^{b}$ & $9.077^{c}$ & $0.359^{a}$ & $6.508^{\mathrm{b}}$ \\
\hline $\mathrm{T} 1 \mathrm{~W} 1 \mathrm{P} 2\left(75^{\circ} \mathrm{C}, 5\right.$ Minutes, Methanol) & $25.339^{a}$ & $9.060^{\mathrm{c}}$ & $0.334^{\mathrm{a}}$ & $7.561 \mathrm{bc}$ \\
\hline $\mathrm{T} 1 \mathrm{~W} 2 \mathrm{P} 1\left(75^{\circ} \mathrm{C}, 7.5\right.$ Minutes, Ethanol) & $21.353^{\mathrm{a}}$ & $8.934^{c}$ & $0.322^{a}$ & $7.47^{\mathrm{bc}}$ \\
\hline T1W2P2 $\left(75^{\circ} \mathrm{C}, 7.5\right.$ Minutes, Methanol & $32.504^{\mathrm{c}}$ & $7.942^{b}$ & $0.365^{\mathrm{a}}$ & $6.364^{\mathrm{a}}$ \\
\hline T2W1P1 (85 ${ }^{\circ} \mathrm{C}, 5$ Minutes, Ethanol) & $24.298^{a}$ & $7.377^{\mathrm{a}}$ & $0.490^{b}$ & $7.533^{c}$ \\
\hline $\mathrm{T} 2 \mathrm{~W} 1 \mathrm{P} 2\left(85^{\circ} \mathrm{C}, 5\right.$ Minutes, Methanol) & $36.269^{c}$ & $8.614^{c}$ & $0.540^{b}$ & $7.615^{c}$ \\
\hline $\mathrm{T} 2 \mathrm{~W} 2 \mathrm{P} 1\left(85^{\circ} \mathrm{C}, 7.5\right.$ Minutes, Ethanol) & $21.248^{a}$ & $10.496^{\mathrm{e}}$ & $0.492^{b}$ & $6.766^{\mathrm{b}}$ \\
\hline T2W2P2 $\left(85^{\circ} \mathrm{C}, 7.5\right.$ Minutes, Methanol & $26.143^{b}$ & $7.537^{\mathrm{a}}$ & $0.565^{c}$ & $7.342^{b}$ \\
\hline T3W1P1 (95 ${ }^{\circ} \mathrm{C}, 5$ Minutes, Ethanol) & $27.194^{b}$ & $9.140^{d}$ & $0.490^{b}$ & $7.845^{c}$ \\
\hline T3W1P2 (95 ${ }^{\circ} \mathrm{C}, 5$ Minutes, Methanol) & $21.458^{a}$ & $10.496^{f}$ & $0.540^{b}$ & $9.222^{d}$ \\
\hline T3W2P1 (95 ${ }^{\circ} \mathrm{C}, 7.5$ Minutes, Ethanol) & $21.021^{\mathrm{a}}$ & $7.357^{a}$ & $0.492^{b}$ & $7.982^{c}$ \\
\hline T3W2P2 $\left(95^{\circ} \mathrm{C}, 7.5\right.$ Minutes, Methanol & $22.248^{a}$ & $9.140^{d}$ & $0.565^{\mathrm{c}}$ & $8.943^{\mathrm{cd}}$ \\
\hline
\end{tabular}

Note: Different letters in columns are significantly different $(p<0.01)$ in Duncan's Multiple Range Tests

The solvents also have an effect, where it is seen that the use of methanol solvents during extraction (maceration) results in higher protein content compared to ethanol solvents. This can be seen from the treatment which gave the highest protein content, namely T2W1P2 (temperature $85{ }^{\circ} \mathrm{C}, 5$ minutes, Methanol) at $36.269 \%$ and the treatment that yields the lowest protein content is $\mathrm{T} 3 \mathrm{~W} 2 \mathrm{P} 1$ (temperature $95{ }^{\circ} \mathrm{C}, 7.5$ minutes, Ethanol) at $21.021 \%$.

According to Winarno (1993), the heating process can cause denatured proteins, meaning that the structure changes due to open hydrogen bonds, resulting in the ability of proteins to bind water to reduce and cause coagulation. This is what causes protein levels to reduce because some proteins were coagulated, settle and get wasted along with water.

The reduction in protein content due to the blanching process in this study was also shown by several other studies (Hefnawy., 2011; Mutiara et al., 2013; Nkafamiya et al., 2010; Mephba et al., 2007; Indriasari et al., 2016).

In addition to protein, the nutrients tested on this product were vitamin $\mathrm{C}$. The results of variance analysis showed that the interaction of all treatments, namely treatment of temperature and time of blanching process and the use of different organic solvents for extraction on Moringa leaves had a very significant effect on vitamin C levels of Moringa leaves flour (Fcount $=150.72>\mathrm{Ftab}=6.93$ ). This means that all treatments affect vitamin $\mathrm{C}$ levels significantly, where the tendency for the higher temperature and time of the blanching process to be applied increases the vitamin $\mathrm{C}$ content of Moringa leaves flour. For the effect of organic solvents on vitamin $\mathrm{C}$ levels of Moringa leaves flour is highly dependent on temperature and blanching time, which was shown in Table 1 if the blanching temperature is $75{ }^{\circ} \mathrm{C}$ (T1), the use of $70 \%$ methanol gave less vitamin $\mathrm{C}$ than $70 \%$ ethanol; if the blanching temperature was $85{ }^{\circ} \mathrm{C}(\mathrm{T} 2)$ and $95{ }^{\circ} \mathrm{C}(\mathrm{T} 3)$, on the contrary $70 \%$ ethanol solvent produced Moringa leaves flour with lower levels of vitamin $\mathrm{C}$.

From Table 1 it was also known that the lowest value of vitamin $\mathrm{C}$ was found in the treatment of T2W1P1 (temperature $85{ }^{\circ} \mathrm{C}, 5$ minutes, ethanol) of $73.77 \mathrm{mg} 100 \mathrm{~g}^{-1}$, while the highest value of vitamin $\mathrm{C}$ is found in the treatment T2W2P1 (temperature $85{ }^{\circ} \mathrm{C}, 7.5$ minutes, ethanol) and T3W1P2 (temperature $95{ }^{\circ} \mathrm{C}, 5$ minutes, methanol) of $104.96 \mathrm{mg} 100 \mathrm{~g}^{-1}$. It can be seen also that the value of vitamin $\mathrm{C}$ levels tends to reduce with increasing temperature and time of the blanching process. According to Nambiar et al (2001), reduced levels of vitamin $\mathrm{C}$ due to the blanching process are caused by vitamin $\mathrm{C}$ being easily soluble in water and unstable at high temperatures.

For vitamin A, the results of variance analysis showed that the interaction of all treatments, namely treatment of 
temperature and time of blanching process and the use of different organic solvents for extraction on Moringa leaves had a very significant effect at the level of $1 \%($ Fcount $=24.32>\mathrm{Ftab}=6.93)$. This means that all treatments affect vitamin A levels significantly, where the tendency for the higher temperature and the blanching process to be applied increases the vitamin A level of Moringa leaf flour. From Table 1 there is also a tendency for vitamin A values which is higher in Moringa leaves flour extracted using methanol when compared with ethanol.

Based on DMRT $(\alpha=1 \%$ ) further test, it was found that the difference in response to vitamin A levels in Moringa leaves after the blanching process was only shown by the treatment of T1W1P1 (temperature $75{ }^{\circ} \mathrm{C}, 5$ minutes Ethanol) of $3590 \mu \mathrm{g} 100 \mathrm{~g}^{-1}$ against T2W1P1 treatment ( temperature of $85{ }^{\circ} \mathrm{C}, 5$ minutes, Ethanol) of $4900 \mu \mathrm{g} 100 \mathrm{~g}^{-1}$, treatment of T2W2P2 (temperature $85^{\circ} \mathrm{C}, 7.5$ minutes, Methanol) of $5650 \mu \mathrm{g} 100 \mathrm{~g} \mathrm{~g}^{-1}$.

In this study, it was seen that the blanching process made vitamin A levels from the leaves of Moringa increase compared to fresh conditions. The treatment of T2W2P2 (temperature $85{ }^{\circ} \mathrm{C}$ for 7.5 minutes, Methanol) and treatment of T3W2P2 (temperature $95{ }^{\circ} \mathrm{C}$ for 7.5 minutes, Methanol) showed that the highest vitamin A of Moringa leaves was $5650 \mu \mathrm{g} 100 \mathrm{~g}^{-1}$. According to Howard et al (1999), carotene in plants is bound to protein compounds, heat treatment such as steaming, cooking and blanching can release bound carotene making it easier to extract and digest.

Furthermore, the water content test was carried out because the products produced were Moringa leaves flour. For food products in the form of flour, water content becomes one of the quality standards that must be considered in order to find out the durability of these products.

The results of the analysis of various water levels showed that the interaction of all treatments, namely the treatment of temperature and time of blanching process and the use of different organic solvents for extraction on Moringa leaves had a very significant effect at the level of $1 \%($ Fcount $=12.95>$ Ftab $=6.93)$. This means that all treatments affect water content significantly, but the treatment that most influences the water content of Moringa leaves flour is temperature, where the tendency of the higher temperature of the blanching process to be applied increases the moisture content of Moringa leaves flour. According to Sari (2010), blanching with hot water blanching has a greater heat transfer efficiency which causes hydrogen bonds to be weaker while water molecules have higher kinetic energy so that they can penetrate easily into the granule causing higher water content.

In general, from this study it can be seen that the use of methanol as a solvent in the extraction process is able to yield Moringa leaves flour with saponin and nutrient levels greater than extraction using ethanol. According to Bernad et al (2009) that the polarity of solvents greatly influences the solubility of a substance. Polar solvents will dissolve polar and ionic substances, this is due to the high polar solvent dielectric constant so that it can easily dissolve substances that have almost the same/near dielectric constant. Methanol has a greater dielectric constant than ethanol, so that polar substances such as saponins and macro nutrients (protein, vitamin $\mathrm{C}$ and vitamin A) dissolve more when using methanol solvents.

\section{Conclusion and Recommendation}

Blanching proved to reduce saponins content on moringa leaves. The result showed that blanching process carried out at $75{ }^{\circ} \mathrm{C}$ (T1) for 5 minutes (W1) and extraction using $70 \%$ ethanol, proved to be able to produce Moringa leaves flour with the lowest saponin content of $0.790 \%$; and the nutritional content still meets the requirements, namely water content $6.508 \%$, protein content $28.705 \%$, vitamin $\mathrm{C}$ level $90.77 \mathrm{mg} 100 \mathrm{~g}^{-1}$ and vitamin A levels $3590 \mu \mathrm{g} 100 \mathrm{~g}^{-1}$. This proved that the variable T1W1P1 produces higher nutritional moringa flour than the control variable.

Based on the results, it was found that the reduction in saponin levels in Moringa leaves flour can only be done by $49 \%$, so there is still a bitter and unpleasant taste in this product. For further research several process modifications can be carried out such as the extraction process using maceration method, carried out by soaking for 72 hours where solvent replacement is carried out every 24 hours. This is to avoid reabsorbing the extracted saponins into the leaves. In addition, it modifies the blanching process where after the leaves are removed from hot water, it is immediately put into ice water to prevent it continue cooking so that the texture of the leaves is not too soft.

\section{Acknowledgement}

The researcher thanked the institution of Politeknik Palu, Tadulako University and the Bogor Spice and Medicinal Plant Research Institute, which provided laboratories and equipments to support this study, and thanked the Ministry of Research, Technology and Higher Education for its support in Young Lecturer Research 
program in 2018.

\section{References}

Adeboye, A. S., \& Babajide, J. M. (2007). Effect of Processing Methods on Antinutrients in Selected Leafy Vegetables. Nigerian Food Journal, 25, 77-87. http://dx.doi.org/10.4314/nifoj.v25i2.50843

Bernad, C., Yenie, E., \& Heltina, D. (2009). Extraction of Dyes from the Mangosteen Skin. Essay. Riau: Chemical Engineering Department, Riau University.

Fuglie, L. J. (2001). The Miracle Tree: Moringa oleifera: Natural Nutrition for the Tropics. Training Manual. Church World Service, Dakar, Senegal. http://www.moringatrees.org/moringa/miracletree.htm

Harborne, J. B. (2006). Phytochemical Method: Guide to Ways to Analyze Plants. Bandung: Bandung Institute of Technology Press.

Hefnawy, T. H. (2011). Effect of Processing Methods on Nutritional Composition and Anti-Nutritional Factors in Lentils (Lens culinaris). Annals of Agricultural Science, 56(2), 57-61. https://doi.org/10.1016/j.aoas.2011.07.001

Horwitz, W., \& Latimer, G. (2010). Official Methods of Analysis of AOAC International - 18th Edition, Revision 3. Thomson Reuters Chicago, USA.

Howard, L. A., Wong, A. D., Perry, A. K., \& Klein, B. P. (1999). $\beta$-Carotene and Ascorbic Acid Retention in Fresh and Processed Vegetables. Journal of Food Science, 64(5), 929-936. https://doi.org/10.1111/j.1365-2621.1999.tb15943.x

Indriasari, Y., Wignyanto, W., \& Kumalaningsih, S. (2016). Effect of Blanching on Saponins and Nutritional Content of Moringa Leaves Extract. Journal of Food Research, 5(3), 55-60. http://dx.doi.org/10.5539/jfr.v5n3p55

Kholis, N., \& Fariz, H. (2010). Bioassay Testing of Infant Biscuit Supplemented with Moringa Leaf Protein Concentrate in Model of Malnutrition Rat. Agricultural Technology Journal, 3(11), 144-151.

Mackar, H. P. S., \& Becker, K. (1996). Nutritional Value and Antinutritional Component of Whole and Ethanol Extracted Moringa Oleifera Leaves. Journal of Feed Science and Tecnology, 63, 211-228. https://doi.org/10.1016/S0377-8401(96)01023-1

Mepba, H. D., Eboh, L., \& Banigo, D. E. B. (2007). Effects Of Processing Treatments On The Nutritive Composition And Consumer Acceptance Of Some Nigerian Edible Leafy Vegetables. African Journal of Food Agriculture Nutrition and Development, 7(1), 1-18

Mutiara, K. T., Harijono, H., Estiasih, T., \& Sriwahyuni, E. (2013). Effect of Blanching Treatments against Protein Content and Amino Acid Drumstick Leaves (Moringa oleifera). Journal of Food Research, 2(1), 101-108. https://doi.org/10.5539/jfr.v2n1p101

Nambiar, V. S., \& Seshadri, S. (2001). Bioavailability Of Beta Carotene From Fresh And Dehydrated Drumstick Leaves In A Rat Model. Journal of Plant Foods for Human Nutrition, 56(1), 83-95. https://doi.org/10.1023/A:1008132503972

Nkafamiya, I. I., Manji, A. J., Modibbo, U. U., \& Umaru, H. A. (2006). Biochemical Evaluation of Casspourea congoensis (Tunti) and Nuclea latifloia (Luzzi). Fruits. Afr. J. Biotechnol., 6(19), 2461-2463.

Nkafamiya, I., Oseameahon, I., Modibbo, U. U., \& Haggai, D. (2010). Vitamins And Effect Of Blanching On Nutritional And Antinutritional Values Of Non-Conventional Leafy Vegetables. African Journal of Food Science, 4(6), 335-341.

Ogbonnaya, E. C., \& Chinedum, E. K. (2013). Bioactive Constituents and In vitro Antioxidant Capacity of Water Leaf (Talinum triangulare) as Affected by Domestic Cooking. European Journal of Medicinal Plants, 3(4), 540-551. https://doi.org/10.9734/EJMP/2013/4577

Sari, T. K. (2010). Effect of Blanching and Immersion Method in Calcium Chloride (CaCl2) to Improve the Quality of French Fries from Potato Tenggo and Crespo Varieties. Essay. Purwokerto: Faculty of Agriculture, Jenderal Sudirman University.

Sengev, A. I., Joseph, O. A., \& Dick, I. G. (2013). Effect of Moringa oleifera Leaf Powder Supplementation on Some Quality Characteristics of Wheat Bread. Journal of Food and Nutrition Science, 270-275. https://doi.org/10.4236/fns.2013.43036

Stahl, E. (1985). Drug Analysis by Chromatography and Microscopy. Translator: Padmawinata, K and I. Sudiro. 
Bandung : ITB Publish.

\section{Copyrights}

Copyright for this article is retained by the author(s), with first publication rights granted to the journal.

This is an open-access article distributed under the terms and conditions of the Creative Commons Attribution license (http://creativecommons.org/licenses/by/4.0/). 